\title{
A RENAISSANCE INTERRUPTED? Debating Personhood THRough a SeXual ACt IN THE TWELFTH-CENTURY CHRISTIANATE AND ISLAMICATE WORLDS
}

\author{
VANJA HAMZIĆ
}

"Our own generation enjoys the legacy bequeathed to it by that which preceded it. We frequently know more, not because we moved ahead by our own natural ability, but because we are supported by the [mental] strength of others, and possess riches that we have inherited from our forebears." So suggested, in the mid-twelfth century, the philosopher John of Salisbury (ca. 1118-1180), only to wryly retort: "Teachers of the arts [...] explain the basic elements of the art and many truths of the science equally as well as, and perhaps even better than do the ancients. Who is content even with what Aristotle gives in his [book] On Interpretation? Who does not add points obtained from other sources?"1

This bold idea-that it was finally possible to outdo "the ancients" in the arts and sciences-was not just a passing fancy for John of Salisbury and his many studious contemporaries; it in fact formed the basis for a proliferation of academic works and universities in western and southern Europe that sought to bridge the worlds previously thought entirely incommensurable and usher in an age of scholasticism that would eventually lead to the fourteenth- to seventeenth-century Renaissance. It also resulted in the phrase "renaissance of the twelfth century"-which, since its first utterance some 150 years ago in French literary studies, continues to animate a fierce debate in medieval scholarship. For the phrase, helpful as it may be to describe an indubitably significant intellectual and cultural renewal, is not without its flaws. How, for instance, can one offer such a charitable description of a century that saw the rise of the inquisition and merciless Christian infighting, the first expulsions of Jews, the intensification of the so-called Reconquista that dealt near-mortal blows to what had been left of Muslim Spain and, of course, all the blood and gore of the Second, Third and German Crusades? Rather than seeing it as a forerunner to an enlightened time, might it not be more suitable to characterize the European twelfth century as an age of profound crisis, for which a "persecuting society" would be a better descriptor? ${ }^{2}$

The present chapter seeks to make a modest contribution to this debate, by guiding the reader's attention to a telltale aspect of high medieval life- that of sexual and gender diversity - and by expanding the view over the twelfth century so as to include the affairs in the Great Seljuq Empire (1037-1194), a vast TurkoPersianate Sunni Muslim state that originated in Anatolia but quickly came to rule over much of the then Islamicate world-only to be reduced back to an Anatolian sultanate at the end of the century. Rather than an exercise in historical comparativism, whose course never quite does run smooth, this chapter proposes that ad- 
dressing a range of situated yet concomitant phenomena relating to gender and sexuality in the twelfth-century Islamicate and Christianate worlds can shed new light on the inherent complexities that befell this period on either side of what was certainly a religio-political if not necessarily an intellectual divide. Moreover, although the historical periods that are usually associated with these two worlds seem to have brushed only briefly against one another-with a Christianate renaissance arguably in the making while the so-called Islamicate "golden age" was almost at its last breath-their collision, if such it was, left an indelible mark on the nascent forms of human personhood in both Christian and Islamic law and theology of the time. These paradigmatic forms of personhood, although largely divergent in their effect on their respective societies then and in the centuries to come, share nonetheless what seems to be a defining feature of twelfth-century intellectual life: that of concordia discors (discordant harmony) or ikhtiläf (permissible scholarly disagreement) at its most vigorous. Although these concepts originate in canon law and Islamic law, respectively, they can arguably be extrapolated as strikingly apt descriptors of what was going on in quite a few other contemporaneous disciplines, too. Might, then, this expanded view over the twelfth century help us reimagine this period as one of stark but internal(ized) disagreements, of enduring paradoxes, of both ruptures and raptures?

What follows amounts to a situated response and, although more general a picture is painted at the outset, it concerns primarily the question of "sodomy" (peccatum sodomiticum, liwatt) in twelfth-century scholarship. Christian concordia discors is analyzed, specifically, through an essentially intra-Benedictine debate that concurrently produced one of the most inclusive conceptualizations of chaste Christian love and spiritual friendship in the works of Aelred of Rievaulx (1110-1167) as well as some of the most damning anti-sodomy scholarship by the likes of St. Peter Damian (ca. 1007-1072) and Peter Cantor of Paris (ca. 1125-1197). Islamic ikhtiläf is exemplified by an intra-Hanafi debate taking place in the Great Seljuq Empire, in which two hermeneutical approaches to the question of liwat emerged that remained mutually exclusive and therefore divided participating jurists (fuqahà) into two camps. Extraordinarily, one of these camps, led by no other than 'Alā' al-Dīn Abū Bakr b. Mas'ūd al-Kāsānì (d. 1191), called malik al-'ulamā') (king of scholars), arrived at the conclusion that liwatt, in principle, was not a punishable offense (in this world). ${ }^{3}$ While "sodomy" was construed as a deed rather than a defining characteristic of a particular type of personhood in both canon and Islamic law, the foregoing debates are, nonetheless, important for our understanding of legal and social aspects of sexual and gender diversity in the twelfth century and, in turn, the way in which certain rapturous pluralities were continued and ruptured-concomitantly.

\section{SAYING THE UNSAYABLE IN CHRISTIAN SCHOLARSHIP}

It is by now an old adage that the "renaissance of the twelfth century" in western and southern Europe was, for the large part, triggered by the demands of a burgeoning urban population with an increasingly independent social status, who demanded literacy and schooling that had previously been an almost exclusive prerogative of aristocracy and clergy. The academic interests of these new urban students varied 
and clearly intersected with those of more "traditional"-especially clericalscholars, to the effect that the studies of law, medicine, philosophy, and theology flourished and significantly expanded both in size and in scope. One of the most paradigmatic shifts was the renewed study and teaching of Roman law in its Justinianian variant, that is, as interpreted and imagined by the Byzantine Emperor Justinian (483-565).

Some six centuries earlier, under Justinian's supervision, Lex Iulia de adulteriis coercendis, an old Roman law on sexual mores introduced by Augustus (63 BCE-14 $\mathrm{CE}$ ) in $17 \mathrm{BCE}$, was invoked in support of the formal (but never quite enforceable) prohibition of what was termed "men's abominable lust with [other] men," which thus became an offense punishable by death. ${ }^{4}$ It probably mattered little to Justinian and his jurists that the new offense was in direct contradiction with the original lex Iulia, which punished only those liable of fornication (stuprum) and adultery (adulterium) with property confiscation and relegation. Rather, the draconian Byzantine punishment was invented probably because Justinian believed that such lustful offenses caused "famine, earthquake, and pestilence to occur" and because, even if unenforced, the new provision would serve as a dire moral warning to his unruly subjects. In order to buttress the moral dimension of the new law, he also resorted to the biblical account of the demise of the city of Sodom-an exegesis already put forward by the patristic scholar St. Augustine of Hippo (354-430).

When revived in the twelfth century in the context of Justinian's Corpus iuris civilis, the early medieval lex Iulia (rather than its original Roman text) came as a surprise to many. "Sexual crimes" in general, both as a concept and as a matter of public concern, did not accrue a considerable laical or ecclesiastical base for much of the first Christian millennium. Instead, sexuality-related issues were considered primarily private- of one's own conscience - and the advice, if any, of a decidedly nonlegal nature was to be found in the penitentials and other "practical" literature for confessors. The renewed thirst for Roman legal thought, or perhaps any legal thought outside of the explicit canonical tradition, was thus perceived as ungodly-even perverse. The emergent students of Justinian's jurisprudence, in the new law-focused universities such as that of Bologna, were decried for engaging in lucrative scientiae (lucrative sciences) of suspect moral worth, while themselves leading morally lax lives. Monks turning their attention to the Corpus iuris civilis were particularly admonished for what seemed as an all too earthly practice. For instance, an excerpt from Canon Nine of the Second Lateran Council, convened by Pope Innocent II ( $\mathrm{r}$. 1130-1143) in 1139, warned that

the evil and detestable practice has grown, so we understand, whereby monks and canons regular, after receiving the habit and making their profession, are learning civil law $[\ldots]$ with a view to temporal gain, in scornful disregard of the rules of their blessed teachers Benedict and Augustine [...]. We decree by apostolic authority that lawbreakers of this kind are to be severely punished. ${ }^{5}$ 


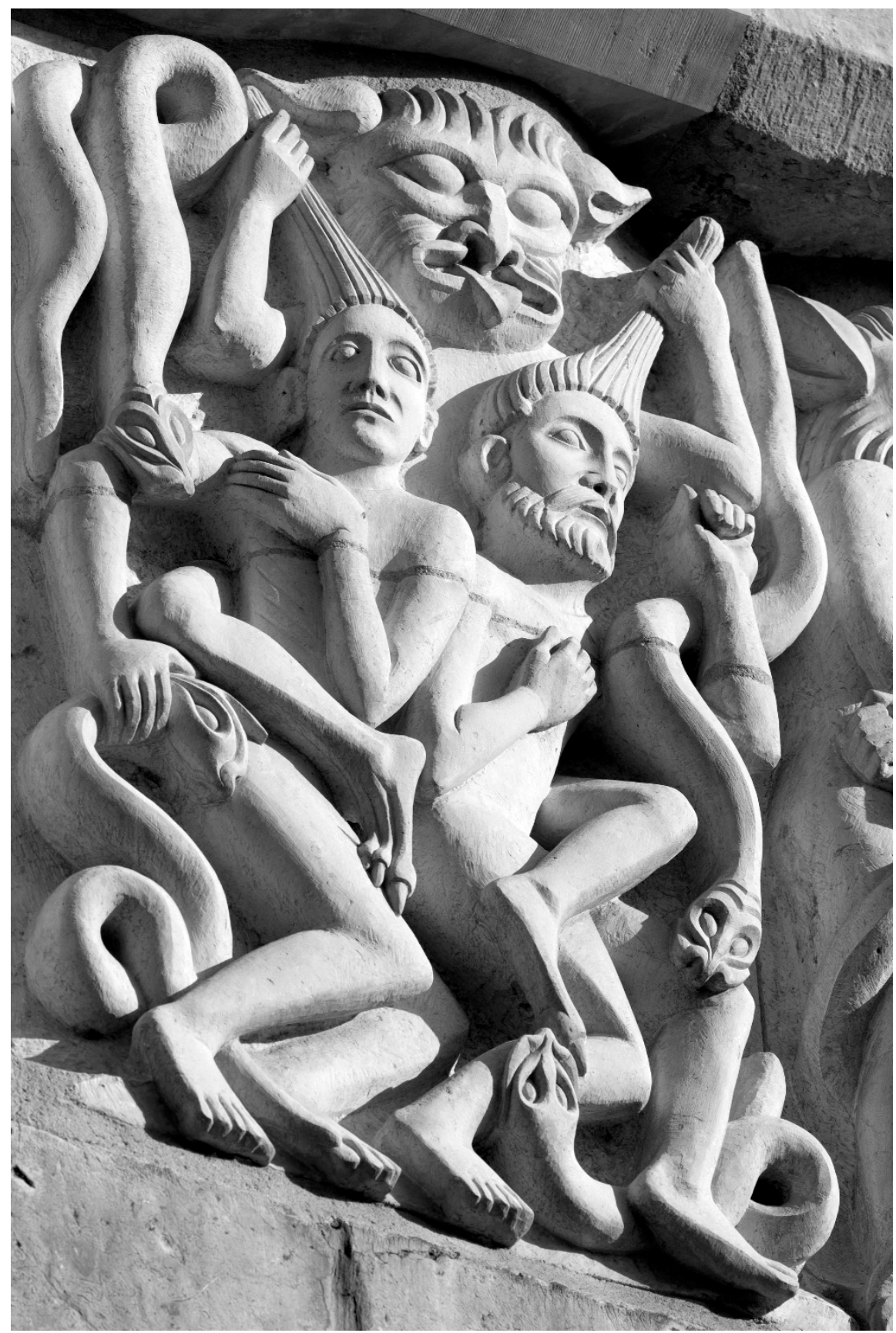

Figure 43.1: Two 'sodomites' in Hell. Romanesque panel on the west frieze of Lincoln Cathedral, c.1141-1148 or c.1160 (restored 1990-2002). Courtesy of Paul Dykes. 
Writing about a decade later in a letter to another pope, the Cistercian reformer Bernard of Clairvaux (1090-1153) toed the same line, explicitly renouncing the Corpus iuris civilis, including the lex Iulia, as un-Christian:

Oh yes, everyday laws resound through the palace, but these are the laws of Justinian, not of the Lord. Is this just? Consider for a moment. Surely, the Law of the Lord is perfect, converting souls. But these are not so much laws as wrangling and sophistry, subverting judgment. Tell me, therefore, how can you, as bishop and shepherd of souls, allow the Law to stand silent before you while these others rattle on? I am at a loss if this perversity does not cause you anxiety. I think that sometimes this should cause you to cry with the Prophet of the Lord, "Evil people have told me tales, but they are not like your Law."6

But the advice was paid little heed. The emerging scholars, jurists, and lawgivers began developing a distinctly expansionist Romano-Christian corpus iuris, with increasingly blurry lines between ecclesiastical (sacerdotum) and public (regnum) authority. This instantiated a curious debate of a distinctly Benedictine character, due to the sheer number of leading Benedictine intellectuals of the time taking part, although an occasional "reformed Benedictine" (Cistercian) theologian, such as-at least nominally-Peter Cantor of Paris, would also weigh in. ${ }^{7}$ The debate, concerning the moral and legal standing of "sodomy", is fascinating not only for its renewed interest in matters that escaped the Church's overt elaboration for nearly a millennium, but also as an ominous precursor to a much darker age in which "sexual crimes" would become an intrinsic part of bloodthirsty public spectacles of justice. By the end of the thirteenth century, much of western and southern Europe saw various forms of capital punishment for "sodomy" swiftly introduced in its neo-Romanized municipal laws: for instance, death by burning in Bologna, castration followed (three days later) by hanging by the legs until death in Portugal, hanging "by the virile members" in Siena, and the death penalty of one's choosing in Tortosa. Could the Benedictine debate in some ways usher in this new age of sexual panic and what certainly amounted to a crisis of masculinity, or did it have a more benevolent character as "mere" concordia discors?

Although the debate reached its peak in the twelfth century, its origins could be traced to the Benedictine monk St. Peter Damian, who published in 1049 his infamous Liber Gomorrbianus. Written while he was prior of Fonte Avellana-an isolated hermitage to which St. Peter Damian strove to introduce a more severe discipline, including the practice of flagellation-this treatise reads more like a hate-filled pamphlet with a strikingly misogynistic overtone. For, all the while addressing men and their perceived "sins," Liber Gomorrbianus makes an explicit claim that the true demonic nature of "sodomy" is feminine, giving her, for example, this vivid description:

This utterly diseased Queen of Sodom [pestilentissima sodomorum regina] renders him who obeys the laws of her tyranny infamous to men and odious to God. She mobilizes him in the militia of the evil spirit and forces him to fight unspeakable wars against God. She detaches the unhappy soul from the company of the angels and, depriving it of its excellence, takes it captive under her domineering yoke $[. .$.$] . She humiliates her slave in the church and condemns bim in court [in foro$ 
condempnat; she defiles him in secret and dishonors him in public; she gnaws at his conscience like a worm and consumes his flesh like fire. ${ }^{8}$

To be sure, such a passionate account of injured masculinity in need of saving from lowly and contagious femininity - in which all sins, including that of sodomy, seemed to inhere-is excessive even for the literature and social mores of its time, especially with respect to the author's open call for legal condemnation. Yet it would not be long before other, similarly charged, writings appeared in a turn that would radically change both the social and the legal landscape of late medieval Europe, which recent feminist scholarship describes as key to the construction of European notions of gender ${ }^{9}$ and — one is tempted to add — sexuality, too.

For some, such as the Benedictine historian William of Malmesbury (ca. 10951143), it seemed more convenient to address "sodomy" as a sin of the upper class, which saw itself independent from Church authority. Writing some twenty-five years after the death of the Norman king William II of England (ca. 1056-1100) whose court had acquired the reputation of a fashionable refuge to poets, musicians, and libertine intellectuals - the Benedictine historian made sure the king's defiant rule be remembered as deprived and abominable. "It was in those days," warned William of Malmesbury, "that the fashion for flowing locks, luxurious clothes, the wearing of shoes with curved points was launched: to rival women in soft living, to mince with foppish gestures and to flaunt naked flesh, was the example set to young men." 10 In a move similar to St. Peter Damian's invocation of his pestilentissima sodomorum regina, William of Malmesbury warned of the mortal dangers of corruptible femininity entering the men's world in both attire and social practice. A few years later, he made an explicit link between such "soft living" and "sodomy":

In times such as these, wanton seduction walked abroad with impunity, and sodomitic lust foully corrupted effeminates destined to the fires of Hell; adultery openly defiled the marriage bed [...]. In those days effeminates ruled the world, unrestrainedly pursued their revels, and foul catamites, doomed to burn in Hell, subjected themselves to the filth of sodomy; [...] they ridiculed the exhortations of priests, and persisted in their barbarous behaviour and dress. ${ }^{11}$

What such writings seemed to exemplify was the rising genre of political literature using gender and sexuality as its ultimate weapons. Although his misogyny must have been as genuine as that of St. Peter Damian, there could be little doubt that William of Malmesbury's fiery writings were primarily intended to reclaim ecclesiastical authority over that represented in King William II's court. The monarch's repeated claims that "questions pertaining to sodomy, dress, hairstyles, incestuous marriages and the like were under the purview of the King, not the Church" 12 must have deeply frightened the Benedictine historian-and so he did his best to denounce them as the sin of a bygone era that the future generations should learn from but never repeat.

"Sodomy" was, however, there to stay as an increasingly political offense. The Knights Templar were suppressed in part for being accused of practicing this "unspeakable vice" (vitium nefandum) — a charge also levied on the Cathars, who were known (and suspicious to others) for their theological rebuttal of marriage. "Sodo- 
my" became an indispensable weapon in political vendettas spanning all middle to upper echelons of late medieval Christianate society, which were further exacerbated by an even more fervent stream of nascent ecclesiastical treatises on the matter. For instance, in 1187 or shortly thereafter, Peter Cantor of Paris published his Verbum abbreviatum, in which he boldly proposed-relying, supposedly, on an account of St. Jerome (ca. 347-420) — that Christ himself had postponed repeatedly his incarnation, unwilling to enter into a human nature defiled by "unspeakable vice." Hence, on the night of Christ's birth, all "sodomites" allegedly died, for-in Peter Cantor's memorable prose- "it was just that the enemies of nature could not endure the advent and splendor of the author of nature himself." 13

This unprecedented vigor of anti-“sodomy" literature contrasted sharply with a surge in widely influential twelfth-century Benedictine and Cistercian treatises on the value of Christian love and spiritual friendship. The leading voice of this popular genre, which provided a powerful-if never quite explicit-counterweight to anti"sodomy" writings, was Aelred of Rievaulx. His works, such as De spiritali amicitia and Speculum caritatis - the latter apparently written at the behest of Bernard of Clairvaux-extolled the value of deep amity between fellow Benedictines, Cistercians, and other Christian contemplative communities. In a famous passage in De spiritali amicitia, Aelred relied on the idea of John the Apostle as Jesus's most beloved disciple to convey what for him was an ideal of godly intimacy in contrast to the more earthly strength of Peter the Apostle: "To Peter [Jesus] gave the keys of his kingdom; to John he revealed the secrets of his heart. Peter, therefore, was the more exalted; John the more secure [...]. Peter [...] was exposed to action, John was reserved for love." 14 Not only was "same-sex" love possible_-it was the most perfect type of Christian being-in-the-world.

While Aelred construed amity as "that virtue by which spirits are bound by ties of love and sweetness, and out of many are made one," he made sure that it was not understood as a purely abstract concept. De spiritali amicitia describes in detail his own passionate amity with fellow brethren, including an unnamed monk with whom he went "through all the stages of friendship, as far as human imperfection permitted," recounting how "love increased between us, affection glowed the warmer and charity was strengthened [at every new level], until we attained that stage at which we had but one mind and one soul to will and not to will alike." 15

The rising rift between those who valued spiritual amity over the politics of flesh was, in itself, an intimate battle-with members of the same monastic order and even the same monastery often finding themselves on the opposite sides of the battle. In decades to come, the "Aelredian" stream moved inwards, providing a spiritual backbone to those whose sexual and gender diversity made them increasingly a target of both Church and state persecution. In contrast, the oppositional "Damianian" faction grew ever more politically powerful and no doubt contributed to an increasingly stark normative outlook of Christianate sexual and gender diversity.

What's more, the Benedictine debate offers a mirror image of the larger countercurrents befalling the twelfth-century Christianate world: the new scholastic impetus was powerfully opposed sometimes from within the very same academic institution; the growing thirst for knowledge coming from Arabic and non-Christian sources contrasted not only with the sheer carnage of the Crusades but with their 
accompanying violent rhetoric, too, which now regularly included a reference to "sodomy" as a "foreign disease." Cardinal Jacques de Vitry (ca. 1166-1240), for example, claimed that the Prophet Muhammad had personally introduced "sodomy" to the Arabs as a means to defile the pure souls of Christian men. ${ }^{16}$ What may have started as concordia discors spiraled into a full-fledged religious and political battle, whose consequences would be felt for centuries. In it, the new ideal types of European "man" and "woman" emerged at the cost of their abounding alterities, once so visible, for example, in Norman-controlled Sicily (1130-1194), where the transition from Muslim to Christian rule was-to a significant extent and in rather ingenious ways-overseen by (male-born castrated) gender-variant individuals (fityān almajābib), whom the Western sources usually call "eunuchs." 17 Both sexual and gender diversity became, in a way, an odious alternative to "chivalrous" (if crusading) masculinity and often cast out as "foreign" and, indeed, "Muslim."

At the same time, a debate similar to the foregoing example of Benedictine concordia discors was led in the Great Seljuq Empire amongst two influential factions of the Hanafi fuqaha - to which this chapter now turns for additional insight into the ways in which certain twelfth-century personhoods both intersected and emerged different in the Christianate and Islamicate lifeworlds of the time.

\section{ISLAMIC INTERSECTIONS OF SIYĀSA AND LIWĀT}

The century and a half of Seljuq domination over Iraq and Persia (1040-1194) reduced the office of the Abbasid caliphs - the once-mighty "deputies of the Prophet"- to that of a largely symbolic player in an increasingly complex pattern of rule in Iraq. Following the decline of the Seljuq dynasty, towards the end of the twelfth century, the Abbasids rose once again to a short-lived renaissance, which was abruptly terminated in 1258, when Mongol armies destroyed Baghdad and massacred its inhabitants. Thus ended not only the Islamicate "golden age" but the so-called classical period of Islamic law, too.

Although an age of continued scientific advances and flourishing arts, including the study of law, the Seljuq period was characterized by social and legal insecurity, not least because the non-Arab, militarized ruling class often felt compelled to make a show of force towards a largely hostile local population. Such public punitive rituals-excessively violent and unpredictable-were a constant feature of the public life of the state. At the same time, the military style of governance also resulted in decentralization, to the extent that both the civil leaders ( $\left.a^{c} y a \bar{n}\right)$ and religious scholars ('ulamā') led their affairs with an extraordinary degree of autonomy. In exchange for this status, however, the military state required that its violent statecraft (siyasa) be vested with religious approval and interpreted as just punishment (the very word siyasa came to mean "punishment" in this period). The Seljuqs believed that excessive forms of public punishment helped to preserve the awe (hayba) that the ruler needed in order to maintain peace, and the local 'ulamä) eventually gave in to the pressure and confirmed this approach as compatible with the sharia. The major effect of this religio-political alliance was, however, a novel approach to the discretionary offenses and punishments $\left(t a^{\top}\right.$ zir $)$ in Islamic law-which no longer required a judge $(q \bar{a} d \grave{\imath})$. Consequently, the police $(s h u r t a)$ or even the market inspector (mubta- 
sib) could freely resort to $t a^{c}$ zir without any consultation with an expert in Islamic law.

Prior to this innovation, $t a^{c}$ zir figured as a reserved discretionary domain of the qädi within the architecture of classical Islamic criminal law, at the top of which sat the so-called budüd (sing. hadd) — a fixed set of crimes and punishments ostensibly found in and mandated by the Qur'ān, which included adultery (zina). Most classical schools of Islamic law (madhähib, sing. madhhab) maintained that "sodomy" (liwatt) is a form of zina and therefore a hadd offense deserving of a Qur'ānically prescribed punishment. But many notable members of the Hanafi madhhab-including its eponymous founder, Abū Haniffa (699-767)—disagreed with that view. Abū Hanifa reasoned that since the penis is not inserted into the vulva, anal sex could not be construed as a hadd but, rather, an offense liable to a ta' zir (discretionary) punishment. Consequently, Hanafi jurists persuaded by this reasoning maintained that the perpetrators of liwat should suffer less than those sentenced for budüd offenses. For instance, if whipping was prescribed, the number of lashes for liwät should never exceed that of the lowest number of lashes in a case of hadd. And, every now and then, this Hanafi approach would have been persuasive even beyond the confines of their school. For instance, it seems that at least some Zāhiri fuqahä followed the same logic, since one of their most notable representatives, the Andalusian philosopher and jurist Ibn Hazm (994-1064), prescribed as few as ten lashes for liwat.t.

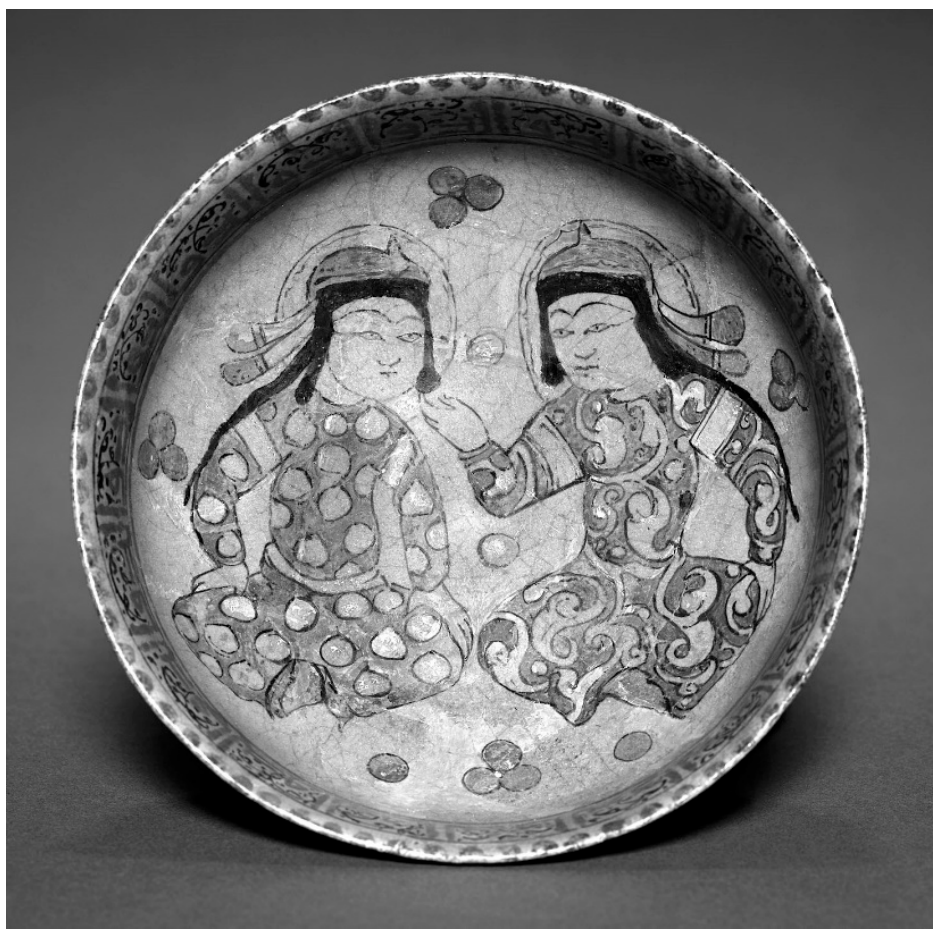

Figure 43.2: Two Seljuks depicted on a bowl. Fritware with overglaze-painted design ( $m i n \bar{a}^{3} i$ ware), probably Kāshān, late twelfth century. Courtesy of the Cleveland Museum of Art, Purchase from the J. H. Wade Fund 1944.478. 
Whether construed as a hadd or a ta' zir offense, classical Islamic law maintained, at least theoretically, its sway over the concept and nature of liwat. The theoretical interest was, in fact, the key generator of such debates, since an actual liwat case would find its way into the qäd $\vec{\imath}$ s courtroom only on a very exceptional and rare occasion. While this, as we shall see, would remain so throughout the Seljuq period as well, that era ushered in a possibility to even theoretically divest from the concept of liwat tand, mutatis mutandis, the qädìs ta' $r i r$-related involvement in the administration of a growing area of state-sanctioned public justice.

This remarkable turn came on the wings of an internal debate on the theological and legal status of liwat, led by an array of influential scholars belonging to the Hanafi madhhab - the school that most Seljuq rulers favored. It therefore carried both theoretical and political purchase. Moreover, as a testament to its far-reaching legal and social significance, the debate can be followed not only in the jurisprudential literature on substantive law $\left(f u r \bar{u}^{c}\right.$ al-fiqh) from the Seljuq period but in some exemplary collections of legal opinions (fataw a) from the same period, too. ${ }^{18}$ It generally divided the participating Hanafi fuqaha $\vec{a}$ into two camps: a minority faction reasoning that liwat must be (re)classified as a hadd and the majority group that found the minority's arguments to be fallacious and arrived, instead, at a truly extraordinary conclusion: that no Qur'ānic injunction, Prophet Muhammad's tradition (hadith), or consensual agreement ( $\ddot{j} m \bar{a})$ ) whatsoever was available that could serve as basis for a legal rule (bukm) against liwät.

The smaller camp, which claimed to rely on some of the earliest Hanafí authorities, such as Abū Yūsuf (ca. 735-798) and Muhammad al-Shaybānī (750-805), considered liwat to be a hadd offense for at least three reasons: (1) the șahāba (the Prophet Muhammad's companions), according to the hadith literature, agreed that it was punishable by death, but disagreed as to the best method of execution; (2) zina and liwat have the same lexical root in the Qur'ānic word for "indecency" (fähisha), so they deserve to be punished equally; and (3) the implied semantic function (ma'na) of the Qur'ānic revelation on liwat tis the same as that of zina. As for the last of these three propositions, the smaller camp argued that zina could be described as a premeditated action aimed at penetrating a genital with another genital (fary) in an impermissible way, while being aware that it is an offense, in order to waste semen, provoked by a natural carnal desire. They further reasoned that all of these elements were present in the act of liwat-_including a natural carnal desire-hence, it needed to be classified as a hadd. Although an impermissible act, then, liwat for this group of fuqaha $\vec{a}$ was clearly a consequence of people's natural dispositions.

The majority camp, led by the famed Hanafī scholar 'Alā' al-Dīn Abū Bakr b. Mas' 'ùd al-Kāsānī, found liwàt to be an essentially unpunishable offense. They arrived at this startling conclusion after a systematic analysis of each of the presented arguments of the opposite camp. (1) The hadith literature discussing the possible methods of execution for the crime of liwat on the authority of the sahāba was all found to be untrustworthy, without exception. (2) The lexicographical argument was rejected on the basis that the two nouns-zina and liwat-describe two different kinds of behavior. One jurist even quoted a verse from the famous libertine poet, Abū Nuwās (d. ca. 815), known for his many affections towards other men, to prove that if zina and liwat were the same, there would be no need for two different 
verbs (zanā and läta) to denote the same action. ${ }^{19}$ (3) The semantic argument of the smaller camp was more complex, so the majority group of the Hanafí jurists took on each of its elements in order to refute it, if need be, in its own right. (a) As far as penetration of a genital with another genital (farj) was concerned, al-Kāsānì̄s teacher and father-in-law 'Alā al-Dīn Muhammad b. Aḥmad al-Samarqandī (d. 1144) recalled, for example, that the definition of zina was, in fact, an unlawful "penetration of the female genital by the male genital" (iläj farj al-rajul fi farj al-mar'a) and explained that inina was committed only if an act of penetration (illaj) involved the qubl (vagina)—not just "any" farj. ${ }^{20}$ (b) The impermissibility of liwat, for this group, was not the point. This act was, unquestionably, morally reprehensible in this world for all the Hanafîs, although some proposed that it could be quite different in the hereafter, where liwaț might be stripped of its social perils and thus reduced to pure pleasure. The point was, rather, that the act did not deserve legal punishment. As with many other forbidden things (haräm), it was up to individual Muslims to resist the temptation of engaging in it. In other words, it was a quintessentially private matter. (c) To know that liwat was an offense implied, for the oppositional minority camp, that they could prove, under any circumstances, that the perpetrators of liwat knew that what they were "acting upon" was not their rightful "property." Sexual acts were, indeed, often legally defined as a part of property law: the permissibility of intercourse depended on whether the "penetrator" lawfully possessed the vagina (qubl) in question. Since qubl was, theoretically, the only "acquirable" farj, the offenders in a liwat case always already knew that what they were doing was legally wrong. The majority Hanafi camp responded to this imputation by reversing the logic of the entire construct: clearly, in liwat al-akbar ("grand," male-male liwàt), the absence of a husband as the only potential "proprietor" in such matters thwarted this line of reasoning, while in liwat al-asghar ("petty" liwat between spouses) the minority's opinion had some merit. In either case, however, the mens rea of the individuals involved was not in itself sufficient to constitute an offense. (d) The majority agreed that the wastage of semen as a by-product of liwat was outright deplorable (mahin), but it also stressed that this act was, at least, safe from the worse perils, such as unwanted procreation, confusion of the lineage, and fatherless life of children born out of wedlock-all of which were potential consequences of the hadd offense of zinā. (e) Finally, the Hanafi majority did not readily disagree with the opposition's proposition that liwat was a product of a natural carnal desire. One jurist opined, for example, that it was as a matter of Qur'ānic principle, rather than natural predispositions, that people differentiated between same-sex and different-sex intimacy.

But, if liwàt was not a hadd, could it still be punishable as a ta'zir offense? We have already seen that, in the Seljuq period, $t a^{c}$ quir became a reserved domain of the state, rather than of the qạdi, so the Hanafi fuqaha $\bar{a}$ made no specific recommendations to that end, nor can such pronouncements be found in the relevant fatwa collections. What's more, not a single trial is recorded, nor an execution or other form of punishment for liwat mentioned, in meticulously kept Seljuq chronicles. ${ }^{21}$ Thus, in the state in which frequent and ruthless public punishments became a defining feature of the ruler's siyasa, liwat remained—in theory and in practice-an unpunishable act. 
How, then, can this realization and the foregoing Hanafi debate be squared with the opposite effect of the Benedictine debate on "sodomy"? And what does this mean for the question of the "renaissance of the twelfth century"?

\section{CONCLUSION}

The eventful twelfth century saw both Christian and Islamic fields of legal theory and practice through what must have felt like a seismic change: the intricate and highly demanding study of divine law in its Christian or Muslim variants, an aloof science reserved for the gifted few, was now facing unlikely competition from a rising legal profession derived from (and primarily interested in enforcing) public authority. While these weren't quite yet "secular" legal formations, the students and proto-lawyers of European municipal law in its newly discovered Justinianian mode as well as the Seljuq police and market inspectors empowered to mete out ta' ${ }^{\mathrm{C}} \mathrm{ir}$ in their own right posed a serious challenge for the elite theologians and jurists. As a result, and not without much clamor, the boundaries of the legal science dealing with divine law had to be reimagined so as to give space, both theoretically and in practice, to public authorities qua lawgivers, their judicial or quasi-judicial agents, and, of course, their own public spectacles of justice.

But a concomitant and for our case indispensable effect of these changes was also one of a deep identity crisis, as exemplified in the internal scholarly disputations on "sodomy" this chapter has sought to illuminate. The Benedictine self, as it were, split between the vision of human personhood in which love takes center stage and an alter ego of traumatic and traumatizing masculinity. The Hanafîs, for their part, as was their custom, engaged in what might seem a more technical debate, in which the devil was in the detail-in particular, in the very possibility that liwat-an act deemed natural if reprehensible-could be construed as legally unpunishable. The majority Hanafí and the "Damianian" camps both drew certain normative contours of human personhood in line with the rising visions of bloodthirsty public justiceit just so happens that they were at the opposite ends with respect to human sexual and gender diversity. For Christianate societies would soon see the "pyres of Sodom" (les bûchers de Sodome) upon which the culprits were burnt to death, while such a sight would remain unimaginable in the Muslim world. For the former, rapturous sexual and gender pluralities were ruptured with utmost violence; for the latter, such raptures continued to flourish.

From this geographically expanded but thematically focused point of view, then, the twelfth century's renaissance was interrupted in its heartlands but continued in the territories that were, in many ways, essential for its commencement in the first place ("the ancients," after all, "spoke again" in that century, in part, because their Greek speech was preserved not in Latin but in the Arabic tongue). This might be a paradox, but it fits quite well the impossible premise of concordia discours - that darling phrase of the twelfth century.

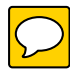


${ }^{1}$ John of Salisbury, The Metalogicon of John of Salisbury: A Twelfth-Century Defense of the Verbal and Logical Arts of the Trivium, trans. Daniel D. McGarry, Berkeley: University of California Press, 1955, p. 167 (references omitted).

${ }^{2}$ Cf. Thomas N. Bisson, The Crisis of the Twelfth Century: Power, Lordship, and the Origins of European Government, Princeton, NJ: Princeton University Press, 2009, and R. I. Moore, The Formation of a Persecuting Society: Authority and Deviance in Western Europe, 950-1250, expanded ed., Oxford: Blackwell, 2007.

${ }^{3}$ For a more comprehensive analysis of these debates, see Vanja Hamzić, Sexual and Gender Diversity in the Muslim World: History, Law and Vernacular Knowledge, London: I.

B. Tauris, 2016, pp. 42-48 and 102-108.

${ }^{4}$ Justinian, Institutes, trans. J. B. Moyle, Oxford: Oxford University Press, 1911, book 4 , title 18 .

${ }^{5}$ Decrees of the Ecumenical Councils, ed. Norman P. Tanner, Washington, DC:

Georgetown University Press, 1990, vol. 1, p. 198. The climate, however, was quickly changing, so much so that the Third Lateran Council, convened in 1179, adopted a canon addressing "that incontinence which is against nature."

${ }^{6}$ Bernard of Clairvaux, Five Books on Consideration: Advice to a Pope, trans. John Anderson and Elizabeth T. Kennan, Washington, DC: Cistercian Publications, 1976, vol. 1, p. 5. De consideratione, written ca. 1150, was addressed to Pope Eugene III (r. 1145-1153).

${ }^{7}$ The first Cistercians were a group of Benedictine monks from the monastery of Molesme, who founded Citeaux Abby in 1098, with the goal of following more closely the Rule of St. Benedict. Bernard of Clairvaux entered the monastery in the early 1110 s with a group of companions and helped the rapid proliferation of the order. Peter Cantor of Paris was a professor and cantor of the cathedral schools in Reims and Paris, but is mentioned in the Cistercian menology as one of themselves because he was taken ill and suddenly died while on a visit to the Cistercians at Long Pont Abbey, and was buried there probably wearing the habit of the order. ${ }_{8}$ Petrus Damiani [St. Peter Damian], Liber Gomorrbianus, in Kurt Reindel (ed.), Die Briefe der Petrus Damiani, Munich: MGH, 1983, vol. 1, p. 310 (emphasis added). 9 Jo Ann McNamara and Suzanne Wemple, "The Power of Women through the Family in Medieval Europe, 500-1100," Feminist Studies 1 (1973), pp. 126-141, here: p. 126.

${ }^{10}$ William Stubbs and Helen J. Nicholson, Chronicle of the Third Crusade: A Translation of the Itinerarium peregrinorum et gesta Regis Ricardi, Aldershot: Ashgate, 2001, pp. 369370. For William of Malmesbury's original text in Latin, see Willelmus Malmesburiensis Monachus, De gestis regum Anglorum, vol. 4, pp. 498-499, collected in Patrologiae cursus completes... series Latina, ed. Jacques Paul Migne, Paris: Garnier, 1899, vol. 179, pp. 1278-1279.

${ }^{11}$ The Ecclesiastical History of Orderic Vitalis, ed. and trans. Marjorie Chibnall, Oxford: Clarendon Press, 1969-80, vol. 4, pp. 186, 188. For the original text, see Willelmus Malmesburiensis Monachus, De gestis regum Anglorum, supra n. 10.

12 William E. Burgwinkle, Sodomy, Masculinity, and Law in Medieval Literature: France and England, 1050-1230, New York: Cambridge University Press, 2004, p. 50. 
13 "Iustum erat, ut auctore naturae nascente morerentur hostes naturae, non valentes sustinere adventum et splendorem ipsus"; quoted in John Baldwin, The Language of Sex: Five Voices from Northern France around 1200, Chicago: University of Chicago Press, 1994, p. 282, n. 5, with a reference to Hugonis de Sancto Charo . . . in epistolis Pauli, Venice, 1703, vol. 7, fol. 209rb.

${ }^{14}$ Aelredus Riaevallensis [Aelred of Rievaulx], De spiritali amicitia, 3.117, as translated in Aelred of Rievaulx, On Spiritual Friendship, trans. Mary Eugenia Laker, Washington, DC: Cistercian Publications, 1974, p. 125. Aelred's opting for spiritalis, instead of the more common spiritualis, apparently indicates the decidedly philosophic, hermeneutic, and speculative context of this work (and its Ciceronian origins).

15 Aelred of Rievaulx, De spiritali amicitia, 3.124, as translated in Aelred of Rievaulx, On Spiritual Friendship, p. 128.

${ }^{16}$ Iacobus de Vitriacus Jacques de Vitry], Historia Hierosolymitana,ed. Jacques Bongars, Paris, 1459 (Free Library of Philadelphia, Rare Book Department), vol. 1, pp. 1055-1056.

${ }^{17}$ For an excellent overview, see Jeremy Johns, Arabic Administration in Norman Sicily: The Royal Diwan, New York: Cambridge University Press, 2002, pp. 212-256.

${ }^{18}$ The discussion of the debate is primarily based on 'Alä' al-Dīn Abū Bakr b.

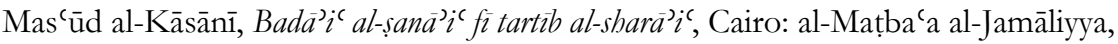
1910, vols. 1-7; Burhān al-Dīn 'Alī b. Abī Bakr b. 'Abd al-Jalīl al-Marghinānī, Bidāyat al-mubtadì, Cairo: Maktabat wa-Mațba'at Muḥammad 'Alī Șubḥ, 1969; 'Alā al-Dīn Muhammad b. Ahmmad al-Samarqandī, Tuhfat al-fuqahä’, Beirut: Dār al-Kutub al-'Ilmiyya, 1984, vols. 1-3; Burhān al-Dīn 'Alī b. Abī Bakr b. 'Abd al-Jalīl alMarghinānī, al-Hidāya sharḥ al-Bidāya, Cairo: Muștafā al-Bābī al-Halabī, 1975; Muhammad b. Ahmmad al-Sarakhsī, Kitāb al-Mabsūṭ, Beirut: Dār al-Ma'rifa, 1993, vols. 1-9; Muhammad b. Aḥmad al-Sarakhsī, Le grand livre de la conduit de l'état [Sharh al-siyär al-kabin, trans. Muhammed Hamidullah, Ankara: Türkiye Diyanet Vakfi, 1989; and fatwa collections such as Abū l-Hasan 'Alī al-Sughdī, al-Fatāwā, 2nd ed., Amman: Dār al-Furqān, 1984, vols. 1-2; Hasan b. Manz̦ūr al-Ūzjandī al-Farghānī Qādịikhān, al-Fatāwāa, Beirut: Dār al-Ma'rifa, 1973; Sirāj al-Dīn 'Alī b. 'Uthmān Ūshī al-Farghānī, al-Fatāwà al-siräjiyyya, Calcutta: n.p., 1827.

${ }^{19}$ Al-Sarakhsī, al-Mabsüt, vol. 9, p. 78.

${ }^{20}$ Al-Samarqandī, Tubfat al-fuqahä), vol. 3, p. 138.

${ }^{21}$ The only records of even remotely suggestive nature pertain to the execution of Sultan Sanjar's (ca. 1084-1157) slave boys Sunqur and Qaymāz-which was the consequence of a court intrigue rather than a ta ${ }^{C}$ ir punishment for liwat - and a note relating that, in 1143, a man was captured and killed by a mob on the streets of Baghdad for an unspecified "indecency" involving a young boy (the term liwat at is not used in the note); see 'Abd al-Rahmān b. 'Alī b. al-Jawzī, al-Muntazam fì ta'rìkeh almulūk wa-l-umam, ed. Mușțafā 'Abd al-Qādir 'Ațā, Beirut: Dār al-Kutub al-'Ilmiyya, 1992, vol. 18, p. 33. 